\title{
Fermentation of Jamaican Cherries Juice Using Lactobacillus plantarum Elevates Antioxidant Potential and Inhibitory Activity against Type II Diabetes-Related Enzymes
}

\author{
Andri Frediansyah ${ }^{1, * \mathbb{C}}$, Fitrio Romadhoni ${ }^{2}$, Suryani ${ }^{3}$, Rifa Nurhayati ${ }^{1}$ and Anjar Tri Wibowo ${ }^{4,5, * \mathbb{C}}$ \\ 1 Research Division for Natural Products Technology (BPTBA), Indonesian Institute of Sciences (LIPI), \\ Yogyakarta 55861, Indonesia; rifa004@gmail.com \\ 2 Department of Chemistry, Faculty of Mathematic and Natural Science, Islamic University of Indonesia (UII), \\ Yogyakarta 55584, Indonesia; kimiajogja2@gmail.com \\ 3 Department of Biology, Faculty of Science and Technology, Sunan Kalijaga Islamic State University (UIN \\ Sunan Kalijaga), Yogyakarta 55281, Indonesia; lactobacilluspentosus@gmail.com \\ 4 Departement of Biology, Faculty of Science and Technology, Airlangga University, Kampus C, Mulyorejo, \\ Surabaya 60115, Indonesia \\ 5 Biotechnology of Tropical Medicinal Plants Research Group, Airlangga University, Kampus C, Mulyorejo, \\ Surabaya 60115, Indonesia \\ * Correspondence: andri.frediansyah@lipi.go.id (A.F.); anjar.tri@fst.unair.ac.id (A.T.W.); \\ Tel.: +62-274-392-570 (A.F.); +62-315-936-501 (A.T.W.)
}

Citation: Frediansyah, A.; Romadhoni, F.; Suryani; Nurhayati, R.; Wibowo, A.T. Fermentation of Jamaican Cherries Juice Using Lactobacillus plantarum Elevates Antioxidant Potential and Inhibitory Activity against Type II Diabetes-Related Enzymes. Molecules 2021, 26, 2868. https://doi.org/ $10.3390 /$ molecules 26102868

Academic Editors: Severina Pacifico and Simona Piccolella

Received: 22 April 2021

Accepted: 10 May 2021

Published: 12 May 2021

Publisher's Note: MDPI stays neutral with regard to jurisdictional claims in published maps and institutional affiliations.

Copyright: (c) 2021 by the authors. Licensee MDPI, Basel, Switzerland. This article is an open access article distributed under the terms and conditions of the Creative Commons Attribution (CC BY) license (https:/ / creativecommons.org/licenses/by/ $4.0 /)$.

\begin{abstract}
Jamaican cherry (Muntinga calabura Linn.) is tropical tree that is known to produce edible fruit with high nutritional and antioxidant properties. However, its use as functional food is still limited. Previous studies suggest that fermentation with probiotic bacteria could enhance the functional properties of non-dairy products, such as juices. In this study, we analyze the metabolite composition and activity of Jamaican cherry juice following fermentation with Lactobacillus plantarum FNCC 0027 in various substrate compositions. The metabolite profile after fermentation was analyzed using UPLC-HRMS-MS and several bioactive compounds were detected in the substrate following fermentation, including gallic acid, dihydrokaempferol, and 5,7-dihydroxyflavone. We also found that total phenolic content, antioxidant activities, and inhibition of diabetic-related enzymes were enhanced after fermentation using L. plantarum. The significance of its elevation depends on the substrate composition. Overall, our findings suggest that fermentation with L. plantarum FNCC 0027 can improve the functional activities of Jamaican cherry juice.
\end{abstract}

Keywords: Jamaican cherry; fermentation; Lactobacillus plantarum; antioxidant; antidiabetic; food nutrition improvement

\section{Introduction}

Jamaican cherry (Muntingia calabura Linn.) is a plant species belonging to Elaeocarpaceae. This plant is indigenous to Southern Mexico, Northern South America, Central America, Trinidad, St. Vincent, and the Greater Antilles [1]. It is also spread and commonly found in other tropical countries including Indonesia, Malaysia, the Philippines, and India [2]. The flower, roots, and barks are used as folk remedies for various medical conditions including fever, liver disease, incipient cold, and antiseptic agents in Southeast Asia [1]. The leaves are known to contain phenolic compounds that exhibits various biological activities such as antimicrobial [3], antioxidant [4], anti-cancer [5], hepatoprotective [6], and hypotensive activities [7]. In addition, Jamaican cherry fruit is edible; they can be eaten raw or processed as juice. Morphologically, the fruit is relatively small, weighted around $1.50 \mathrm{~g}$, round smooth-shape, and the color turns from green to red when ripened. It has a sweet taste due to low titratable acidity and high content of soluble solids. The fruit is also known to have high nutritional value [8] and contain high concentration of flavonoid and 
phenolic compounds [9]. Due to its taste, nutritional value, and high content of antioxidant compounds, Jamaican cherry fruit has a great potential to be used as a functional food in the food industry.

In previous work, we reported the isolation of lactic acid bacteria from Jamaican cherry fruit [10]. Despite their abundance and diversity, little is known about lactic acid bacteria natural physiological function. Nevertheless, these bacteria are widely known in the food industry due to their probiotic properties [11]. Fermentation using lactic acid bacteria was reported to enhance the flavor [12], shelf life [13], bioavailability [14], and functional quality of the fermented substrates [15]. Our previous study showed that fermentation of black grape juice using Lactobacilli could increase juices' functional properties in vitro [16]. The use of L. pentosus and Leuconostoc in the fermentation of carrot juice also shown to improve the bioavailability of iron in the juice [17]. Another study showed that lactic bacteria and other associated microorganisms in kefir could elevate the $\alpha$-glucosidase inhibitory effect of Aronia melanocarpa fruit juice [18]. The market interest and demands for functional food are continuously increasing [19], aforementioned studies suggest that probiotics bacteria could be used to enhance the functional properties of non-dairy products such as juices. In this study, we use L. plantarum strain FNCC 0027 for the fermentation of Jamaican cherry juice. Six different substrate compositions were tested and functional properties of the fermented juices in each of the substrate compositions were reported, including phenolic content, antioxidant capacity, and the inhibition of several type II diabetes-related enzymes. Further, we also provided the metabolite profile of the fermented juice. Here we showed that Jamaican cherry juice fermentation using L. plantarum FNCC 0027 can effectively improve functional properties of the juice.

\section{Results and Discussion}

\subsection{Fermentation of Jamaican Juice by L. plantarum}

Fermentation using various substrate compositions containing different ratios of Jamaican cherry juice and MRS broth (M1 to M6) was monitored for $48 \mathrm{~h}$. As shown in Figure 1A. the initial viable count of L. plantarum was $7.02 \log \mathrm{CFU} / \mathrm{mL}$ and the initial $\mathrm{pH}$ was 6.51. The rapid growth of L. plantarum was observed after $4 \mathrm{~h}$ of fermentation while the $\mathrm{pH}$ of the substrate continuously declined in an opposite trend. The viable count of L. plantarum reached a maximum at $24 \mathrm{~h}$ and was maintained until $48 \mathrm{~h}$. The highest viable count observed was $9.3 \operatorname{logs} \mathrm{CFU} / \mathrm{mL}$ at $24 \mathrm{~h}$ in M6, followed by M5, M4, M2, M1, and $\mathrm{M} 3$ with 8.9, 8.6, 8.4, 8.5, and $8.5 \log \mathrm{CFU} / \mathrm{mL}$, respectively (Figure $1 \mathrm{~A}$ ). Our data showed that the growth rate of L. plantarum was positively correlated with the amount of MRSB in the substrate. Propagation of viable cells and growth pattern are crucial for the production of desired metabolite in the fermented substrate. Østlie, et al. [20] reported that the production of organic acid, carbon dioxide, and volatile compounds was influenced by the total cell count of probiotic L. acidophilus, L. rhamnosus, L. reuteri, and Bifidobacterium animalis in the fermented substrate. On the other hand, L. plantarum viable count was negatively correlated with substrate $\mathrm{pH}$, while the viable count is increasing the $\mathrm{pH}$ is decreasing over the fermentation period $(p<0.05)$ (Figure 1B). The $\mathrm{pH}$ value of the substrate is an essential parameter to assess the progress and endpoint of the fermentation; it was reported to influence the flavor of the final product [21]. After $48 \mathrm{~h}$ of fermentation, the $\mathrm{pH}$ of the fermented juices has decreased from 6.5 to 3.3 (M1), 3.4 (M2), 4 (M3), 3.7 (M4), 3.4 (M5), and 3.9 (M6). This pattern is quite similar to the 48-h-fermentation of Indonesian black grape juice using L. plantarum [16]. 
(A)

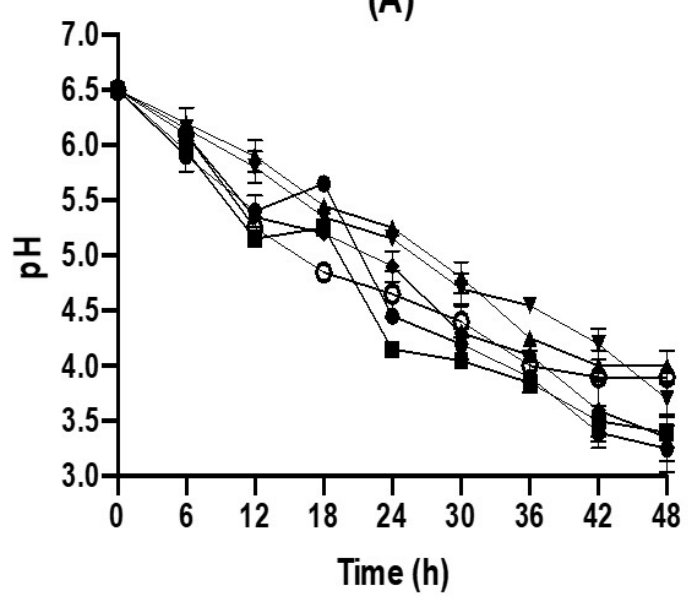

(B)

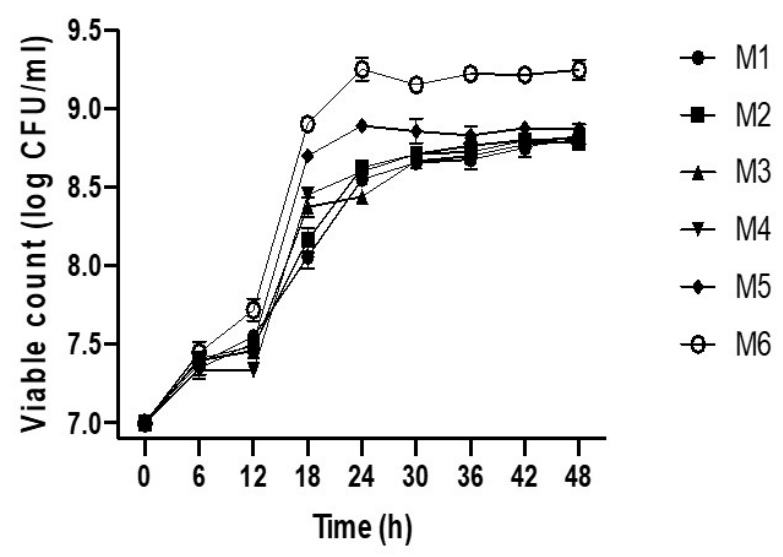

Figure 1. Effect of fermentation on $\mathrm{pH}$ and viable count (A) the change of $\mathrm{pH}(\mathbf{B})$ viable count.

\subsection{Total Phenolic Content after Fermentation}

The fruit of Jamaican cherry are reported to be rich in phenol, flavonoid, and other bioactive substances [8]. Phenols are essential antioxidants in fruit and vegetables, therefore, in this study we evaluated total phenolic content in different substrates formulation (M1 to M6) before and after fermentation. Our data revealed that fermentation using L. plantarum can significantly increase total phenolic compounds in M1 and M2 formulation to about 1.3and 1.4-folds $(p<0.05)$, respectively (Figure 2$)$. This result is in consonance with published studies about fruit fermentation using L. plantarum, including in the fermentation of blueberry [22], mulberry [23], and kiwi juice [24]. Changes in total phenolic content in the substrate might occur through multiple factors. For example, changes in substrate $\mathrm{pH}$ during fermentation period could affect the structure of the phenolic compound [22]. Alternatively, a macromolecular form of phenol can be disintegrated into small phenols due to specific metabolic activity of the lactic acid bacteria, such as de-glycosylation [23]. Lactobacillus fermentation does not always have a positive effect on phenol concentration. Liao, et al. [25] reported that fermentation using L. brevis MPL39 can significantly reduce phenolic content in mango juice. Therefore, it should be considered that different lactic acid bacteria strains and substrate matrices could have different effects on the phenolic content.

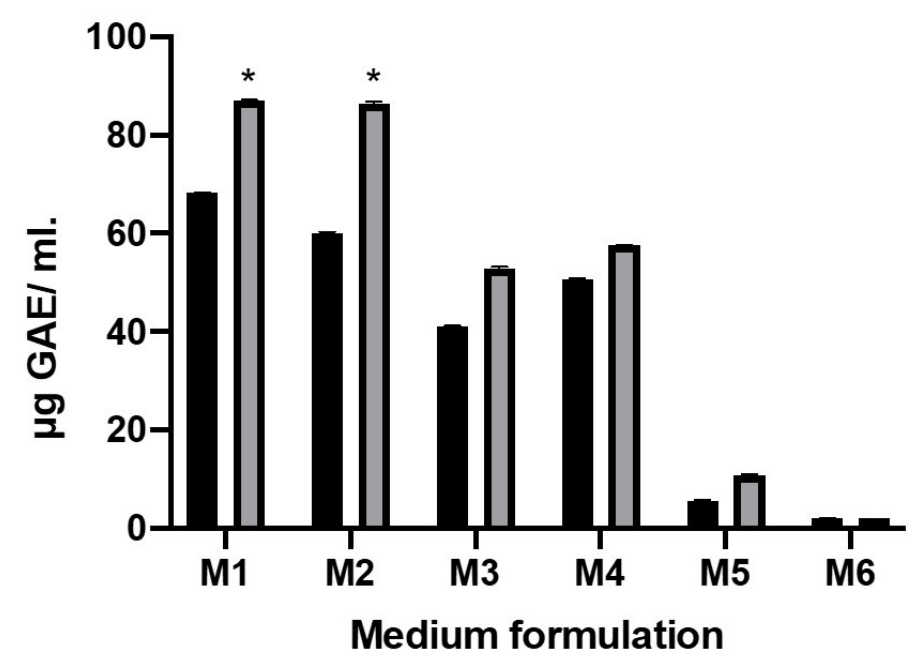

Figure 2. Effect fermentation of L. plantarum on the total phenol content. Black bar represent phenol content before fermentation and gray bar represent phenol content after fermentation. Each value represents the mean $\pm \mathrm{SE}(\mathrm{n}=3)$. The star $\left.{ }^{*}\right)$ means significantly different at $p<0.05$. 


\subsection{Antioxidative Activity of the Fermented Juices}

Antioxidants that present in fermented substrates, such as polyphenol and flavonoid, can eliminate free radicals through electron donation or hydrogen atom transfer. Various types of antioxidative compounds may act against oxidizing agents through diverse mechanisms [26,27]. The antioxidant activity of Jamaican cherry fruit has been reported in previous study [8], which attributed to the presence of polyphenol, flavonoid, and vitamin $\mathrm{C}$ in the fruit [28]. Fermentation with lactic acid bacteria could improve the bioavailability of fruits' natural constituents [14]. Here we performed four assays for assessing the antioxidant capacity of fermented Jamaican cherry juice (M1-M6), including DPPH radical, ABTS cation radical, FRAP, and ORAC assay (Figure 3).

The highest DPPH scavenging activity was observed in fermented M1 that contains $100 \%$ of Jamaican cherry juice, showing $77.81 \%$ DPPH activity, comparable to gallic acid $(76.77 \%)$ and ascorbic acid (85.57\%) that were used as positive control in the experiment. The fermented M1 to M3 substrates exhibited enhanced DPPH scavenging activity compared to their respective non-fermented controls; it was 1.7, 1.8, and 2.2 times higher in fermented M1 to M3, respectively (Figure 3A). Overall, fermented M1 to M3 showed more than $50 \%$ of radical scavenging activity after $48 \mathrm{~h}$ of fermentation using L. plantarum. Similar enhancement in DPPH radical scavenging following fermentation has been reported in previous studies $[16,23]$. The ABTS radical scavenging activity is also elevated after $48 \mathrm{~h}$ fermentation. Similar to DPPH activity the highest ABTS scavenging activity was observed in fermented M1 that contains 100\% Jamaican cherry juice, showing $69.25 \%$ ABTS activity. Gallic acid and ascorbic acid exhibited $75.43 \%$ and $73.45 \%$ ABTS activity, respectively. Comparing fermented and non-fermented group, significant increase in ABTS activity was observed in the fermented M1 to M4 ( $p \leq 0.05)$, where 1.70; 1.46; 1.47; and 1.76-fold increase in ABTS activity was recorded, respectively (Figure 3B). FRAP (Figure 3C) and ORAC (Figure 3D) values also showed a similar trend. M1 and M2 antioxidative activity significantly elevated $(p \leq 0.05)$ after fermentation using L. plantarum. The FRAP and ORAC values for both M1 and M2 are 1.3 times higher following $48 \mathrm{~h}$ fermentation

Generally, we showed that $L$. plantarum could elevate antioxidant activity of Jamaican cherry juice, additionally we observed that substrate containing $100 \%$ (M1) and $80 \%$ (M2) Jamaican cherry juice could significantly increase $(p \leq 0.05)$ antioxidant activity in all tested assays. Suggesting that higher juice content in the substrate correlates with higher antioxidative activity. This results was consistent with our previous study about black grape juices fermentation with L. plantarum [16]. Several recent studies also showed the enhancement of antioxidant capacity in fruit juices fermented using lactic acid bacteria, such as in kiwifruit [24], dragon fruit [29], apple [30], and bergamot [31]. Fermentation using lactic acid bacteria could increase the concentration of functional components like phenolic and flavonoids compounds through hydrolysis mechanisms [32]. In addition, the $\mathrm{pH}$ change during fermentation could also influence the phytochemical structure of antioxidant compounds [33]. Further, changes in $\mathrm{pH}$ could alter the activity of various metabolic enzymes and increase the bioavailability of various compounds [16].

\subsection{Enzyme Inhibition Ability}

Controlling postprandial hyperglycemia is an essential part of diabetes treatment. This could be achieved by reducing or inhibiting the absorption of glucose during the digestion step. There are numerous pathways to prevent the absorption of glucose, one strategy is by inhibiting $\alpha$-glucosidase, $\alpha$-amylase, and amyloglucosidase activity. These three enzymes are essential hydrolase that could metabolize carbohydrates and regulate the blood sugar level in the human body. Various extracts from bacteria, fungi, and plants, including fruit, leaves, roots, and roots were reported to be able to inhibit diabetes-related enzymes activity [16,34]. Recent study showed that fermentation using probiotic bacteria, including lactic acid bacteria, could increase the antidiabetic potential of blueberry juice [22] Such study is essential for the development of fermentation based functional beverages. Here we reported $\alpha$-glucosidase, $\alpha$-amylase, and amyloglucosidase inhibition by different 
formulations (M1-M6) of Jamaican cherry juice fermentation using L. plantarum. Overall, significant increase in the inhibition of $\alpha$-glucosidase, $\alpha$-amylase, and amyloglucosidase activity $(p<0.05)$ was observed in M1 to M4 following fermentation for 48 h (Figure 4). The highest increase in inhibition against $\alpha$-glucosidase (1.9 times) and amyloglucosidase (1.6 times) was recorded in fermented M2, while the highest increase in inhibition against $\alpha$-amylase (1.9 times) was observed in fermented M1. Acarbose, a well-known antidiabetic drug, a positive control in this study, showed higher but comparable inhibitory properties against those three enzymes (Figure 4). These results indicate that fermentation of Jamaican cherry fruit juice using L. plantarum can improve the inhibitory activities of the juice and their antidiabetic potential. The increase in inhibitory activities of plant extract against diabetes-related enzymes following L. plantarum fermentation is in agreement with previous studies $[16,22,35]$. Further, the cell-free filtrate of L. plantarum X1 was also reported to be able to inhibit $\alpha$-glucosidase activity [36].

(A)

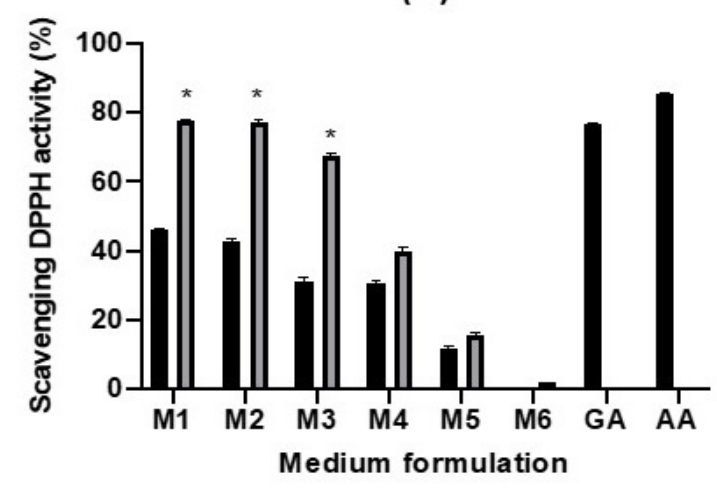

(C)

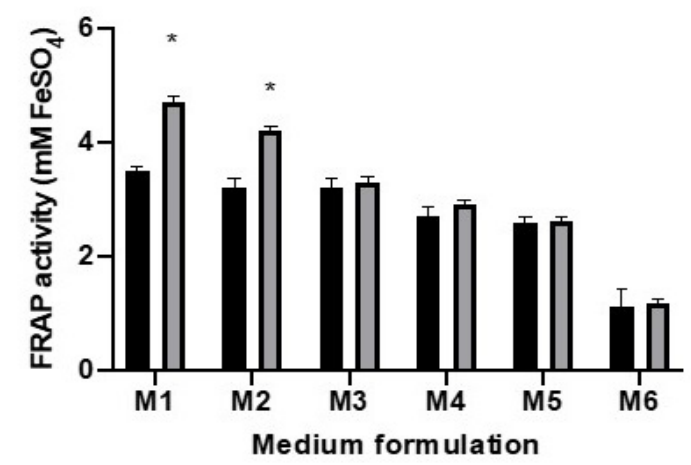

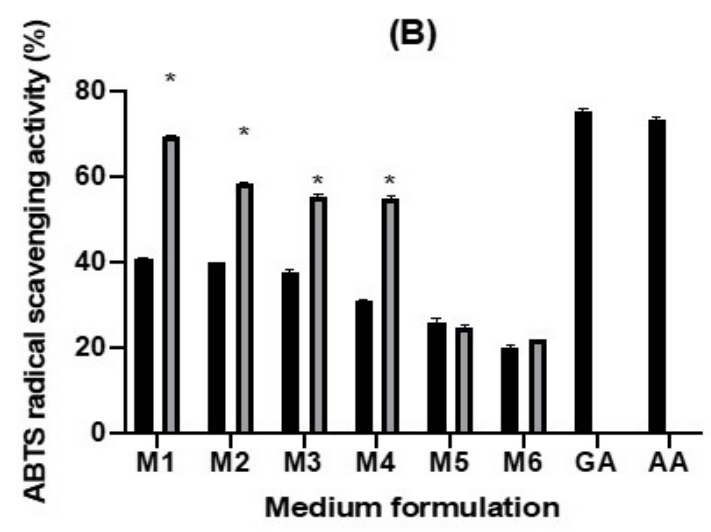

(D)

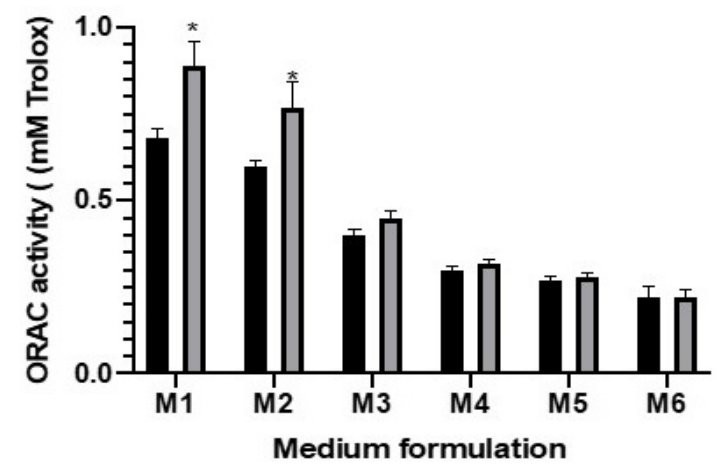

Figure 3. The effect of fermentation by L. plantarum on the antioxidant activities of Jamaican cheery juices. (A) Scavenging DPPH activity (B) ABTS Scavenging radical activity (C) FRAP activity (D) ORAC activity. Black bar represent antioxidant activities before fermentation and gray bar represent antioxidant activities after fermentation. Each value represents the mean \pm SE $(\mathrm{n}=3)$. The $\operatorname{star}\left(^{*}\right)$ means significantly different at $p<0.05$.

Structural changes of indigenous compounds following fermentation might contribute to the inhibition activity. It is reported that fermentation of Momordica charantia (bitter melon) juice using L. plantarum BET003 results in the transformation of aglycone compounds and improved antidiabetic potential of the fermented juice [37]. In addition, fermentation might enhance the activity various proteolytic enzymes that can inhibit amylase and amyloglucosidase activity, such as protamex, alcalase, neutrase, and flavourzyme [16]. 
(A)

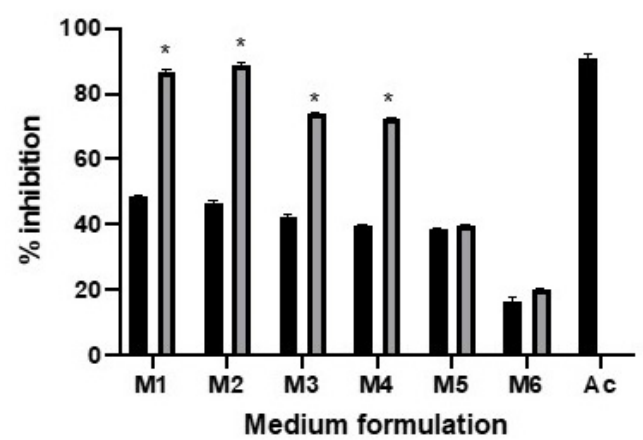

(C)

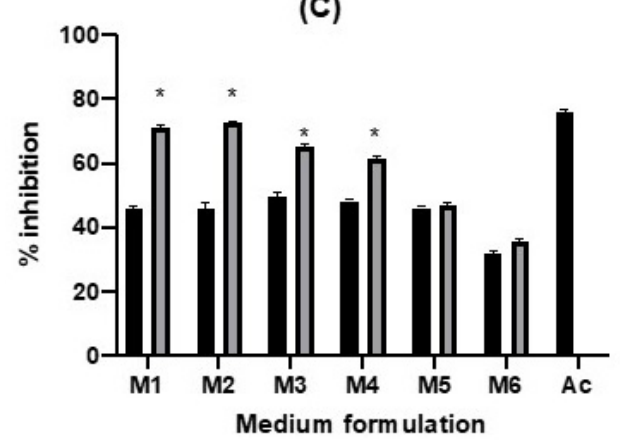

(B)

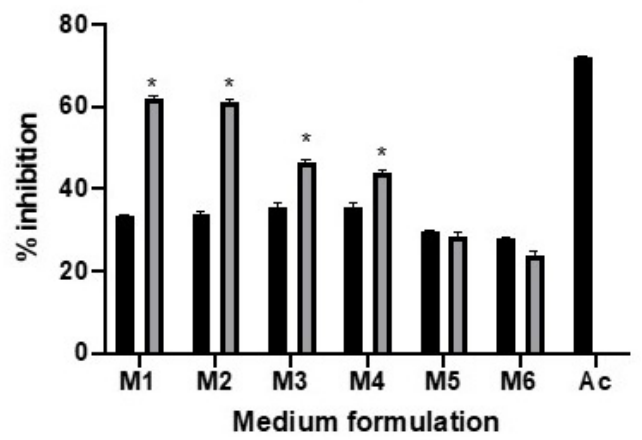

Figure 4. Effect fermentation of L. plantarum to the inhibition of $(\mathbf{A}) \alpha$-glucosidase, $(\mathbf{B}) \alpha$-amylase, and (C) amyloglucosidase. Black bar represent inhibitory activities before fermentation and gray bar represent inhibitory activities after fermentation M1 to M6 means medium formulation and Ac means Acarbose $5 \mathrm{mg} / \mathrm{mL}$. Each value represents the mean \pm SE ( $\mathrm{n}=3$ ). The star $\left(^{*}\right)$ means significantly different at $p<0.05$.

\subsection{Mass Spectrometry Analysis of M1 Substrate}

Our results showed that total phenolic content, antioxidant activities, and inhibitory activity against diabetes-related enzymes was highest in substrate with $100 \%$ Jamaican cherry juice. To evaluate whether those activities are correlated with changes in metabolite composition of the fermented juice, we analyzed the metabolite profile of the fermented and unfermented M1 using UHPLC-QTOF-HRMS/MS. The electrospray ionization mode was set into a negative mode, three more peaks were detected in the fermented M1 namely A, $\mathrm{B}$, and C (Figure 5). We then annotate the putative metabolites A, B, and C using molecular formula and the fragmentation pattern against database, aided with spectral library search together with the suggested fragmentation trees using SIRIUS (https://bio.informatik. uni-jena.de/software/sirius / [accessed 20 June 2020]). We identified the three putative metabolites of fermented Jamaican fruit juice, including gallic acid (A), dihydrokaempferol (B), and 5,7-dihydroxyflavone (C) (Table 1 and Figures S1-S3).

A previous study reported that L. plantarum strain CIR1 could produce gallic acid during fermentation. This bacteria could produce tannase, an enzyme that could facilitate bioconversion of tannic acid to gallic acid [38]. L. plantarum strain FNCC 0027 used in this study might also produce tannase that can hydrolyze tannic acid presence in Jamaican fruits $[8,39]$. Recent study reported that fermentation of Solanum retroflexum leaf using $L$. plantarum strain 75 could induce the production of various bioactive compounds, such as gallic acid, vanillic, coumaric, ellagic acid, quercetin, and catechin [40]. Fermentation with L. plantarum FNCC 0027 also induces the production of bioactive compounds, including gallic acid, dihydrokaempferol, and 5,7-dihydroxyflavone. The production of dihydrokaempferol possibly due to the L. plantarum shikimic pathway that can convert flavonoid naringenin presents in Jamaican fruit into dihydrokaempferol [8]. Hydroxylation of naringenin by hydroxylase enzyme known to be produced by L. plantarum could produce intermediate compounds from dihydroflavonols class, such as dihydrokaempferol and 
dihydroxyflavone [41-43]. Gallic acid and flavonoids such as dihydrokaempferol and 5,7-dihydroxyflavone is known to have antidiabetic and antioxidant properties [44-46]. Thus, their presence in the fermented substrate can influence the functional properties of the Jamaican cherry juice.

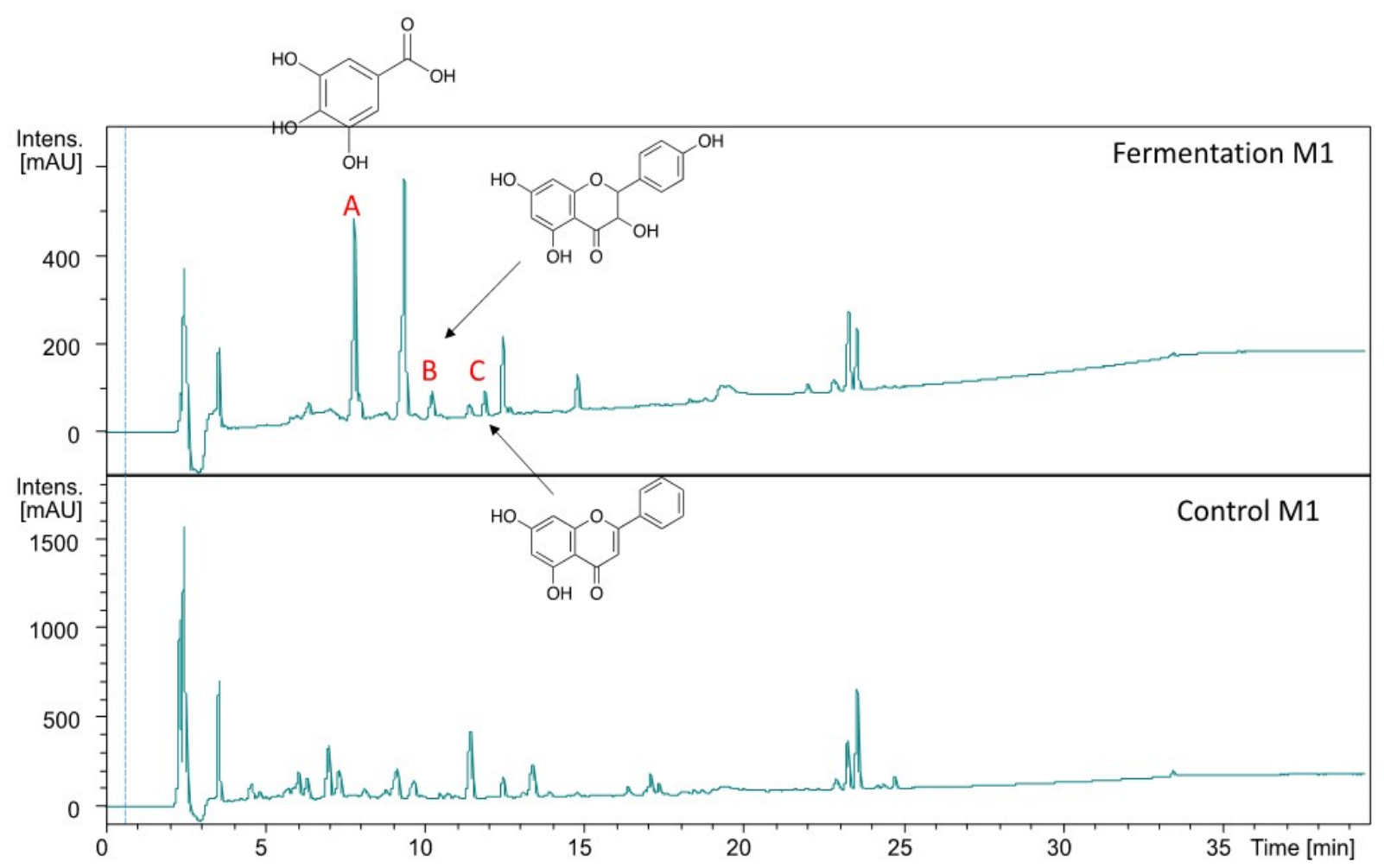

Figure 5. The UV chromatogram of M1 containing L. plantarum (above) and M1 without L. plantarum (below).

Table 1. Chemical constituent identified after fermentation of M1 using L. plantarum.

\begin{tabular}{|c|c|c|c|c|c|c|}
\hline Peak & Putative Compound & Experiment $(m / z)$ & Theoretical $(\mathrm{m} / \mathrm{z})$ & Adduct & Error (ppm) & $\mathbf{r d b}$ \\
\hline $\mathrm{A}$ & gallic acid & 169.0141 & 169.0142 & {$[\mathrm{M}-\mathrm{H}]^{-}$} & 0.7 & 5 \\
\hline $\mathrm{B}$ & dihydrokaempferol & 287.0561 & 287.0561 & {$[\mathrm{M}-\mathrm{H}]^{-}$} & -0.1 & 10 \\
\hline $\mathrm{C}$ & 5,7-dihydroxyflavone & 253.0505 & 23.0506 & {$[\mathrm{M}-\mathrm{H}]^{-}$} & 0.5 & 11 \\
\hline
\end{tabular}

$\mathrm{rdb}$ means ring double bond.

\section{Materials and Methods}

\subsection{Chemical and Reagents}

The chemicals and reagents used are p-nitrophenyl- $\alpha$-D-glucopyranoside $\left(\right.$ Calbiochem ${ }^{\circledR}$, San Diego, MA, USA), starch (Merck, Darmstadt, Germany), acarbose (Fluka Analytical, Sigma-Aldrich, Laramie, WY, USA), Man Rogosa Sharpe/MRS broth (Sigma-Aldrich, St. Louis, MO, USA), $\alpha$-glucosidase from Saccharomyces cerevesiae (Sigma-Aldrich, St. Louis, MO, USA), $\alpha$-amylase from Aspergillus oryzae (Sigma-Aldrich, St. Louis, MO, USA), amyloglucosidase from Aspergillus niger (Sigma-Aldrich, St. Louis, MO, USA), 2,2-Diphenyl-1-picrylhydrazyl (Sigma-Aldrich, St. Louis, MO, USA), 2,4,6-Tris(2-pyridyl)s-triazine (Fluka Analytical, Sigma-Aldrich, St. Louis, MO, USA), 3,5-dinitrosalicylic acid (Sigma-Aldrich, St. Louis, MO, USA), 2,2'-Azino-bis(3-ethylbenzothiazoline-6-sulfonic acid) (Sigma-Aldrich, St. Louis, MO, USA), Folin-Ciocalteu's phenol reagent (Merck, Darmstadt, Germany), gallic acid, peroxidase. Other reagents were analytical grade or better. 


\subsection{Bacterial Strain and Fruit Material}

Lactobacillus plantarum FNCC 0027 was obtained from the culture collection of Biotechnology Laboratory, Graduate School of Biotechnology, Universitas Gadjah Mada, Yogyakarta, Indonesia. Jamaican cherry fruits were collected from the research field at Research Division for Natural Product Technology (BPTBA), the Indonesian Institute of Sciences (LIPI), Yogyakarta, Indonesia in March 2016. The fruits ( $250 \mathrm{~g})$ were washed and kept at $4{ }^{\circ} \mathrm{C}$ before further use. Jamaican cherry juice was produced from the fruit using sterilized-commercial food juicer at room temperature.

\subsection{Preparation of Inoculant}

L. plantarum FNCC 0027 were propagated in MRS broth at $37^{\circ} \mathrm{C}$ for $48 \mathrm{~h}$ under anaerobic conditions. The cells were harvested, pelletized, and re-suspended in sterilized phosphate buffer saline at $7.02 \log \mathrm{CFU} / \mathrm{mL}$ for inoculation.

\subsection{Fermentation Procedure}

First, Jamaican cherry juice was produced by homogenizing Jamaican cherry fruits with sterile water in a commercial blender at the concentration of $1 \mathrm{~g} / \mathrm{mL}$. The homogenized juices were filtered and pasteurized for $3 \mathrm{~min}$ at $85^{\circ} \mathrm{C}$ [20]. Fermentation was performed in $250 \mathrm{~mL}$ sterilized Erlenmeyer. Erlenmeyer was filled with pasteurized Jamaican cherry juice (J) and sterilized MRS broth (M) with a total reaction volume of $100 \mathrm{~mL}$. Six different $\mathrm{J}$ to $\mathrm{M}$ ratios were used in this study (in a total of $100 \mathrm{~mL}$ ), including M1 (1:0), M2 (4:1), M3 (3:1), M4 (1:1), M5 (1:4), and M6 (0:1). Each formulation was subjected to two treatments: control non-fermented group and group fermented using L. plantarum (with an initial starter of $7.02 \log \mathrm{CFU} / \mathrm{mL}$ ). All samples were then incubated aerobically at $37^{\circ} \mathrm{C}, 100 \mathrm{rpm}$, for $48 \mathrm{~h}$ before harvested for subsequent analysis.

\subsection{Bacterial Cell Separation}

To obtain cell-free supernatant, the fermented juices were centrifuged for $15 \mathrm{~min}$ at $10,000 \times g$ [47]. The resulting supernatant was then filtered through a $0.22 \mu \mathrm{m}$ membrane filter (Millipore, Burlington, MA, USA) and kept at $-20^{\circ} \mathrm{C}$.

\subsection{Bacterial Viable Count}

Viable count was performed at different intervals over the course of $48 \mathrm{~h}$ fermentation $(0,6,12,18,24,30,36,42$, and $48 \mathrm{~h})$. To perform viable count, 10 sterile $15 \mathrm{~mL}$ test tubes were filled with $9 \mathrm{~mL}$ of sterilized phosphate buffer saline (PBS). Serial 10-fold dilutions in PBS were then prepared in the test tubes, using $1 \mathrm{~mL}$ of fermented juice as the starter. Viable count was next performed using pour plate method in duplicate, $1 \mathrm{~mL}$ of solution from each dilution series was mixed with $25 \mathrm{~mL}$ tempered $\left(47^{\circ} \mathrm{C}\right)$ Plate Count Agar (OXOID ${ }^{\circledR}$, Basingstoke, England). The plate was incubated for $72 \mathrm{~h}$ at $30^{\circ} \mathrm{C} \pm 2{ }^{\circ} \mathrm{C}$, and colony numbers was calculated using a colony counter. Plates with 15 to 300 colonies were considered for colony forming unit calculation. The viable colonies were converted into weighted mean colony forming units per milliliter $(\mathrm{CFU} / \mathrm{mL})$ using the following Equation (1):

$$
\mathrm{N}=\sum \mathrm{C} /\left[\left(\mathrm{n}_{1}+0.1 \mathrm{n}_{2}\right) \mathrm{d}\right]
$$

$\mathrm{N}$ is the number of colonies in the plate; $\sum \mathrm{C}$ is the sum of plates containing 15 to 300 colonies; $\mathrm{n}_{1}$ is the number of plates retained in the first dilution; $\mathrm{n}_{2}$ is the number of plates retained in the second dilution; and $\mathrm{d}$ is the first dilution factor. The viable colonies were then converted into $\log \mathrm{CFU} / \mathrm{mL}$.

\section{7. $\mathrm{pH}$ Measurement}

The $\mathrm{pH}$ of the samples was measured using Eutech PC $700 \mathrm{pH}$ meter (Thermo Scientific, Waltham, MA, USA). The $\mathrm{pH}$ measurement was performed at different intervals over the course of $48 \mathrm{~h}$ fermentation $(0,6,12,18,24,30,36,42$, and $48 \mathrm{~h})$. 


\subsection{Total Phenolic Content Measurement}

Total phenolic content was determined using methods developed by Zhou, Wang, Zhang, Yang, Sun, Zhang, and Yang [24], with minor modifications. Briefly, $25 \mu \mathrm{L}$ of $0.2 \mathrm{~N}$ Folin-Ciocalteu phenol reagents was added into 96-well plates containing $5 \mu \mathrm{L}$ of each supernatant and $195 \mu \mathrm{L}$ of distilled water. The mixture was then incubated for $6 \mathrm{~min}$ at room temperature in darkness, followed by addition of $75 \mu \mathrm{L}$ of $7 \%$ sodium carbonate. The mixture was then incubated further for $2 \mathrm{~h}$ at room temperature in darkness. Blank solution was prepared by the same steps as described above except that supernatant was substituted with $5 \mu \mathrm{L}$ of water. For all samples, the absorbance at $765 \mathrm{~nm}$ was recorded using Multiskan ${ }^{\circledR}$ Go microplate spectrophotometer (Thermo Scientific, Vantaa, Finland). Standard curve was produced using Gallic acid, the equation for the standard curve is $\mathrm{y}=0.0104 \mathrm{x}-0.0159\left(\mathrm{R}^{2}=0.9988\right)$ where $\mathrm{y}$ is the absorbance at $735 \mathrm{~nm}$ and $\mathrm{x}$ is the concentration of Gallic acid in $\mu \mathrm{g} / \mathrm{mL}$. Total phenol was expressed as $\mu \mathrm{g}$ of Gallic acid equivalent (GAE) per $\mathrm{mL}$ of supernatant ( $\mu \mathrm{g} \mathrm{GAE} / \mathrm{mL}$ ).

\subsection{2,2-Diphenyl-1-picrylhydrazyl (DPPH) Radical Scavenging Activity}

The DPPH scavenging assay was performed using 96-well plates following the method by Kosem, et al. [48], with modifications. Briefly, $50 \mu \mathrm{L}$ of filtered supernatant was mixed with $70 \mu \mathrm{L}$ of methanol and the absorbance of the pre-plate reading was recorded at $517 \mathrm{~nm}$. About $80 \mu \mathrm{L}$ of $0.5 \mathrm{mM}$ DPPH solution in methanol was then added to the well. The degree of purple (from DPPH) decolorization to yellow represents the scavenging efficiency of the supernatants. After an incubation period of $30 \mathrm{~min}$ at room temperature $\left(25 \pm 2{ }^{\circ} \mathrm{C}\right)$ in the darkness, the decrease in the absorbance was recorded at $517 \mathrm{~nm}$ using Multiskan ${ }^{\circledR}$ Go microplate spectrophotometer (Thermo Scientific, Vantaa, Finland). Lower absorbance represents higher free radical-scavenging activity. The scavenging activity against DPPH was calculated using following Equation (2):

$$
\text { DPPH scavenging rate }(\%)=\left[1-\left(\mathrm{Abs}_{1}-\mathrm{Abs}_{0}\right)\right] \times 100 \%
$$

$\mathrm{Abs}_{0}$ was absorbance of control and $\mathrm{Abs}_{1}$ was the absorbance in the presence of supernatant.

\subsection{2,2'-Azino-bis(3-ethylbenzothiazoline-6-sulfonic acid) (ABTS) Assay}

The ABTS assay was performed according to Re et al. [49]. In brief, radical cation was generated by reacting $5 \mathrm{~mL}$ of $7 \mathrm{mM}$ ABTS with $5 \mathrm{~mL}$ of $2.45 \mathrm{mM}$ of potassium persulfate. The reaction was performed by incubating the mixture for $16 \mathrm{~h}$ in the dark. Working solution for radical cation was obtained by diluting the reacted solution at the OD $0.7 \pm$ 0.02 at $734 \mathrm{~nm}$. Subsequently, $300 \mu \mathrm{L}$ of the diluted radical cation solution was mixed with $3 \mu \mathrm{L}$ of supernatant. The ODs was then recorded at $734 \mathrm{~nm}$ after $10 \mathrm{~min}$ incubation at room temperature using Multiskan ${ }^{\circledR}$ Go microplate spectrophotometer (Thermo Scientific, Vantaa, Finland). The ABTS radical scavenging activity was calculated using Equation (2).

\subsection{Ferric Reducing-Antioxidant Power (FRAP) Assay}

The FRAP assay was conducted according to Cecchini and Fazio [50], which was originally described by Benzie and Strain [51], with minor modifications. In brief, FRAP reagent was prepared by mixing $300 \mathrm{mM}$ sodium acetate buffer ( $\mathrm{pH} 3.6), 10 \mathrm{mM}$ of 2,4,6Tris(2-pyridyl)-s-triazine (TPTZ) in $40 \mathrm{mM} \mathrm{HCl}$, and $20 \mathrm{mM} \mathrm{FeCl}_{3} \cdot 6 \mathrm{H}_{2} \mathrm{O}$ at 10:1:1 (v/v/v) ratio. Subsequently, $10 \mu \mathrm{L}$ of supernatant was added to the 96-well plate containing $300 \mu \mathrm{L}$ FRAP solution as an oxidizing reagent. After $5 \mathrm{~min}$ incubation in dark at $37^{\circ} \mathrm{C}$, the absorbance was measured at $593 \mathrm{~nm}$ using Tecan Infinite ${ }^{\circledR} 200$ Pro microplate reader. The experiment was calibrated with $\mathrm{FeSO}_{4} \cdot 7 \mathrm{H}_{2} \mathrm{O}$ and the results were expressed in terms of $\mathrm{FeSO}_{4} \cdot 7 \mathrm{H}_{2} \mathrm{O}$ equivalents $(\mu \mathrm{M})$. 


\subsection{Oxygen Radical Absorbance Capacity (ORAC) Assay}

ORAC were measured according to Zulueta, et al. [52]. The 2,2'-Azobis(2-amidinopropane) dihydrochloride (AAPH) radical stock solution was prepared freshly by adding $434 \mathrm{mg}$ of AAPH to $10 \mathrm{~mL}$ of phosphate buffer $(75 \mathrm{mM})$ to obtain final concentration of $161 \mathrm{mmol} / \mathrm{L}$. Fluorescein stock solution $(1.03 \mathrm{mmol} / \mathrm{L})$ was prepared using phosphate buffer solution. Subsequently, the supernatant $(25 \mu \mathrm{L})$ was added to the 96-well plate and mixed with $150 \mu \mathrm{L}$ of fluorescein solution $(40 \mathrm{~nm} / \mathrm{L})$. Mixture was then incubated for $5 \mathrm{~min}$ at $37^{\circ} \mathrm{C}$. Subsequently, $25 \mu \mathrm{L}$ AAPH solutions was added and the fluorescein was recorded immediately at an excitation wavelength of $485 \mathrm{~nm}$ and emission wavelength of $535 \mathrm{~nm}$. The fluorescein was monitored using Tecan Infinite ${ }^{\circledR} 200$ Pro microplate reader every minute for $30 \mathrm{~min}$, ORAC values were expressed in term of Trolox equivalents $(\mu \mathrm{M})$.

\subsection{In Vitro Inhibiting Activity of $\alpha$-Glucosidase}

The $\alpha$-glucosidase inhibitory activity of the fermented supernatant was determined according to the chromogenic method, in a 96-well plate, according to our previous published method [16]. First, $20 \mu \mathrm{L}$ of supernatant was mixed with $10 \mu \mathrm{L}$ of a $1.0 \mathrm{U} / \mathrm{mL} \alpha$-glucosidase and $50 \mu \mathrm{L}$ of $0.1 \mathrm{M}$ sodium phosphate buffer ( $\mathrm{pH}$ 6.9). The mixed solution was incubated at $37^{\circ} \mathrm{C}$ for $15 \mathrm{~min}$. After pre-incubation, the enzymatic reaction was initiated by adding $20 \mu \mathrm{L}$ of $5 \mathrm{mM}$ p-nitrophenyl- $\alpha$-D-glucopyranoside solution in $0.1 \mathrm{M}$ sodium phosphate buffer ( $\mathrm{pH}$ 6.9). The mixture was incubated for $20 \mathrm{~min}$ at $37^{\circ} \mathrm{C}$. The absorbance was subsequently measured at $405 \mathrm{~nm}$ using Multiskan ${ }^{\circledR}$ Go microplate spectrophotometer (Thermo Scientific, Vantaa, Finland). Percent inhibition was calculated relative to the diabetes drug acarbose as the reference. Reaction system without supernatant was used as negative control while reaction system without $\alpha$-glucosidase was used as a blank for correcting the background absorbance. The percentage of enzymatic inhibition activity was calculated using following Equation (3):

$$
\% \text { inhibition activity }=\left[\left(\mathrm{Abs}_{\mathrm{A}}-\mathrm{Abs}_{\mathrm{B}}\right) / \mathrm{Abs}_{\mathrm{A}}\right] \times 100 \%
$$

$\mathrm{Abs}_{\mathrm{A}}$ is the absorbance of the control and $\mathrm{Abs}_{\mathrm{B}}$ is the absorbance of the tested supernatant.

\subsection{In Vitro Inhibiting Activity of $\alpha$-Amylase}

The $\alpha$-amylase inhibitory activities of the fermented supernatant were carried out according to procedure reported by Telagari and Hullatti [53]. The assay system was carried out in a 96-well plate. First, a reaction mixture containing $10 \mu \mathrm{L}$ of a $2.0 \mathrm{unit} / \mathrm{mL}$ $\alpha$-amylase, $50 \mu \mathrm{L}$ sodium phosphate buffer $(0.1 \mathrm{M}, \mathrm{pH}=6.9)$, and $20 \mu \mathrm{L}$ of supernatant was prepared. The mixed solution was incubated at $37^{\circ} \mathrm{C}$ for $20 \mathrm{~min}$. After pre-incubation, $50 \mu \mathrm{L}$ of $1 \%$ soluble starch (Merck, Darmstadt, Germany) in $0.1 \mathrm{M}$ sodium phosphate buffer $\mathrm{pH} 6.9$ was added as a substrate and the mixture was incubated further for $30 \mathrm{~min}$ at $37^{\circ} \mathrm{C}$. Next, $100 \mu \mathrm{L}$ of the 3.5-dinitrosalicylic acid solution was added and heated at $100{ }^{\circ} \mathrm{C}$ in a water bath for $10 \mathrm{~min}$. The absorbance was subsequently measured at $540 \mathrm{~nm}$ using Multiskan ${ }^{\circledR}$ Go microplate spectrophotometer (Thermo Scientific, Vantaa, Finland). Acarbose was used as a positive reference standard. The percentage of $\alpha$-amylase inhibition was calculated using Equation (2).

\subsection{In Vitro Inhibiting Activity of Amyloglucosidase}

The amyloglucosidase (exo-1,4- $\alpha$-glucosidase) inhibitory activities of the fermented supernatant was carried out in 96-well plate according to Saul et al. [54] and Warren et al. [55], with modifications. First, a mixture containing $10 \mu \mathrm{L}$ of a $1.0 \mathrm{U} / \mathrm{mL} \alpha$-amyloglucosidase, $10 \mu \mathrm{L}$ of $0.1 \mathrm{M}$ sodium acetate ( $\mathrm{pH} 5.0$ ), and $25 \mu \mathrm{L}$ of supernatant was prepared. The mixed solution was incubated at $37^{\circ} \mathrm{C}$ for $20 \mathrm{~min}$. After pre-incubation, the enzymatic reaction was initiated by adding $5 \mu \mathrm{L}$ of $5 \mathrm{mM}$ p-nitrophenyl- $\alpha$-D-glucopyranoside solution in $0.1 \mathrm{M}$ sodium phosphate buffer ( $\mathrm{pH}$ 6.9). At the end of the incubation, $200 \mu \mathrm{L}$ of $0.4 \mathrm{mM}$ 
glycine buffer ( $\mathrm{pH}$ 10.4) was added to each well to stop reaction. The p-nitrophenil released was then measured at $410 \mathrm{~nm}$ using Tecan Infinite ${ }^{\circledR} 200$ Pro microplate reader.

\subsection{UPLC-HRMS-MS Analysis}

High resolution MS was carried out using Bruker maXis 4G ESI time of flight massspectrometer (Bruker Daltonics, Bremen, Germany) attached to an Ultimate 3000 HPLC (Thermo Fisher Scientific, Bremen, Germany). The UHPLC-method was performed using Reprosil $3 \mu \mathrm{m}$ C18 $100 \AA, 10 \times 3.3 \mathrm{~mm}$ (flow rate of $0.3 \mathrm{~mL} / \mathrm{min}$, monitored at 210 and $240 \mathrm{~nm})$ with linear gradient starts from $90 \%$ to $0 \%$ of $\mathrm{A}\left(\mathrm{A}: \mathrm{ddH}_{2} \mathrm{O}, \mathrm{B}\right.$ : Acetonitrile, both solvents containing $0.01 \%$ formic acid) for $30 \mathrm{~min}$ and held constant of $100 \% \mathrm{~B}$ for $10 \mathrm{~min}$. The parameter was set in a capillary voltage of $4500 \mathrm{~V}$, nebulizer nitrogen pressure of 2 bars, the dry gas flow of $9 \mathrm{~L} / \mathrm{min}$ source temperature, ion source temperature $200{ }^{\circ} \mathrm{C}$, and spectral rate of $3 \mathrm{~Hz}$. The MS data subsequently analyzed using Bruker Compass Data Analysis 4.4 SR1(x64).

\subsection{Statistical Analysis}

All assays were conducted in triplicate. The mean and standard error (mean $\pm \mathrm{SE}$ ) was determined of each data. The analysis of variance (ANOVA) and student $t$-test was employed using SPSS 16 to determine the level of statistical differences between control and Jamaican juice formulation fermented with L. plantarum. Differences at $p<0.05$ were considered statistically significant.

\section{Conclusions}

Our results demonstrated that fermentation of Jamaican cherry juice using L. plantarum FNCC 0027 could significantly improve the functional activities of the substrates, including higher polyphenol content, antioxidant capacity (DPPH, ABTS, FRAP, and ORAC), and inhibitory activity against diabetic-related enzymes ( $\alpha$-glucosidase, $\alpha$-amylase, and amyloglucosidase). Various fermentation formulations with different ratios of Jamaican cherry juice and MRSB volume were studied in this study and we found that M1 formulation with $100 \%$ Jamaican cherry juice showed the highest functional activities compared to the other composition. This result indicates that the addition of MRSB is not required to facilitate effective fermentation and improvement of Jamaican cherry juice functional properties. In summary, the functional properties and beneficial activity of Jamaican cherry juice can be enhanced by fermentation with L. plantarum, one of "generally regarded as safe" (GRAS) strain. This work can be used as the basis for the development of new functional beverages using fermented Jamaican cherry juice as the main component.

Supplementary Materials: The following are available online, Figure S1: Peak A found in fermented Jamaican cherry juice with a negative HR-ESI-TOF-MS $m / z 235.0506$ [M-H] ${ }^{-}$; Figure S2: Peak B found in fermented Jamaican cherry juice with a negative HR-ESI-TOF-MS $m / z$ 169.0140 [M-H]-; Figure S3: Peak $C$ found in fermented Jamaican cherry juice with a negative HR-ESI-TOF-MS m/z $287.0561[\mathrm{M}-\mathrm{H}]^{-}$.

Author Contributions: Conceptualization, formal analysis, writing-original draft, investigation, validation A.F.; methodology, data curation, data analysis F.R.; methodology, visualization, software S.; project administration, resources, R.N.; project administration, funding acquisition, supervision, writing-review and editing, A.T.W. All authors have read and agreed to the published version of the manuscript.

Funding: This research was funded by the DIPA -Indonesian Institute of Science (LIPI) and Research Group Grant from Universitas Airlangga (Grant numbers 458 343/UN3.14/PT/2020).

Institutional Review Board Statement: Not applicable.

Informed Consent Statement: Not applicable.

Data Availability Statement: Publicly available datasets were analyzed in this study. This data can be found at: https:/ / www.kaggle.com/microbiologii/dataset-plantarum (accessed on 20 June 2020). 
Acknowledgments: The authors thank Gross for provided us equipment and facilities in the Pharmaceutical Institute, Eberhard Karls Universität Tübingen, Germany, to conduct some assays and mass spectrometry.

Conflicts of Interest: We declare that we have no known competing financial interests or personal relationships that could have appeared to influence the work reported in this paper. We also declare that there is no conflict of interest in the submission of the manuscript and the manuscript is approved by all authors for publication.

Sample Availability: Samples of fermented extracts are not available from the authors.

\section{References}

1. Mahmood, N.; Nasir, N.; Rofiee, M.; Tohid, S.M.; Ching, S.; Teh, L.; Salleh, M.; Zakaria, Z. Muntingia calabura: A review of its traditional uses, chemical properties, and pharmacological observations. Pharm. Biol. 2014, 52, 1598-1623. [CrossRef]

2. Harshini, V.; Gayathri, H.S.; Padmaja, A. Development of Muntingia calabura Fruit Based Squash. Asian J. Dairy Food Res. 2020, 9 , 256-260.

3. Buhian, W.P.C.; Rubio, R.O.; Valle, D.L., Jr.; Martin-Puzon, J.J. Bioactive metabolite profiles and antimicrobial activity of ethanolic extracts from Muntingia calabura L. leaves and stems. Asian Pac. J. Trop. Biomed. 2016, 6, 682-685. [CrossRef]

4. Zolkeflee, N.K.Z.; Isamail, N.A.; Maulidiani, M.; Abdul Hamid, N.A.; Ramli, N.S.; Azlan, A.; Abas, F. Metabolite variations and antioxidant activity of Muntingia calabura leaves in response to different drying methods and ethanol ratios elucidated by NMR-based metabolomics. Phytochem. Anal. 2021, 32, 69-83. [CrossRef] [PubMed]

5. Sufian, A.S.; Ramasamy, K.; Ahmat, N.; Zakaria, Z.A.; Yusof, M.I.M. Isolation and identification of antibacterial and cytotoxic compounds from the leaves of Muntingia calabura L. J. Ethnopharmacol. 2013, 146, 198-204. [CrossRef]

6. Zakaria, Z.A.; Mahmood, N.D.; Mamat, S.S.; Nasir, N.; Omar, M.H. Endogenous Antioxidant and LOX-Mediated Systems Contribute to the Hepatoprotective Activity of Aqueous Partition of Methanol Extract of Muntingia calabura L. Leaves against Paracetamol Intoxication. Front. Pharmacol. 2018, 8, 982. [CrossRef]

7. Shih, C.-D.; Chen, J.-J.; Lee, H.-H. Activation of nitric oxide signaling pathway mediates hypotensive effect of Muntingia calabura L. (Tiliaceae) leaf extract. Am. J. Chin. Med. 2006, 34, 857-872. [CrossRef]

8. Pereira, G.A.; Arruda, H.S.; de Morais, D.R.; Eberlin, M.N.; Pastore, G.M. Carbohydrates, volatile and phenolic compounds composition, and antioxidant activity of calabura (Muntingia calabura L.) fruit. Food Res. Int. 2018, 108, 264-273. [CrossRef]

9. Recuenco, M.C.; Lacsamana, M.S.; Hurtada, W.A.; Sabularse, V.C. Total phenolic and total flavonoid contents of selected fruits in the Philippines. Philipp. J. Sci. 2016, 145, 275-281.

10. Frediansyah, A.; Nurhayati, R.; Sholihah, J. Lactobacillus pentosus isolated from Muntingia calabura shows inhibition activity toward alpha-glucosidase and alpha-amylase in intra and extracellular level. In IOP Conference Series: Earth and Environmental Science; IOP Publishing: Bristol, UK, 2019; p. 012045.

11. Zielińska, D.; Kolożyn-Krajewska, D. Food-origin lactic acid bacteria may exhibit probiotic properties. Biomed. Res. Int. 2018, 2018. [CrossRef]

12. Chen, C.; Lu, Y.; Yu, H.; Chen, Z.; Tian, H. Influence of 4 lactic acid bacteria on the flavor profile of fermented apple juice. Food Biosci. 2019, 27, 30-36. [CrossRef]

13. Parada, J.L.; Caron, C.R.; Medeiros, A.B.P.; Soccol, C.R. Bacteriocins from lactic acid bacteria: Purification, properties and use as biopreservatives. Braz. Arch. Biol. Technol. 2007, 50, 512-542. [CrossRef]

14. Sharma, N.; Angural, S.; Rana, M.; Puri, N.; Kondepudi, K.K.; Gupta, N. Phytase producing lactic acid bacteria: Cell factories for enhancing micronutrient bioavailability of phytate rich foods. Trends Food Sci. Technol. 2020, 96, 1-12. [CrossRef]

15. Szutowska, J. Functional properties of lactic acid bacteria in fermented fruit and vegetable juices: A systematic literature review. Eur. Food Res. Technol. 2020, 246, 357-372. [CrossRef]

16. Frediansyah, A.; Nurhayati, R.; Romadhoni, F. Enhancement of antioxidant activity, $\alpha$-glucosidase and $\alpha$-amylase inhibitory activities by spontaneous and bacterial monoculture fermentation of Indonesian black grape juices. In AIP Conference Proceedings; AIP Publishing LLC: Melville, NY, USA, 2017; p. 020022.

17. Bergqvist, S.W.; Andlid, T.; Sandberg, A.-S. Lactic acid fermentation stimulated iron absorption by Caco-2 cells is associated with increased soluble iron content in carrot juice. Br. J. Nutr. 2006, 96, 705-711.

18. Du, X.; Myracle, A.D. Fermentation alters the bioaccessible phenolic compounds and increases the alpha-glucosidase inhibitory effects of aronia juice in a dairy matrix following in vitro digestion. Food Funct. 2018, 9, 2998-3007. [CrossRef] [PubMed]

19. Siro, I.; Kápolna, E.; Kápolna, B.; Lugasi, A. Functional food. Product development, marketing and consumer acceptance-A review. Appetite 2008, 51, 456-467. [CrossRef]

20. Østlie, H.M.; Helland, M.H.; Narvhus, J.A. Growth and metabolism of selected strains of probiotic bacteria in milk. Int. J. Food Microbiol. 2003, 87, 17-27. [CrossRef]

21. McFeeters, R. Fermentation microorganisms and flavor changes in fermented foods. J. Food Sci. 2004, 69, FMS35-FMS37. [CrossRef]

22. Zhang, Y.; Liu, W.; Wei, Z.; Yin, B.; Man, C.; Jiang, Y. Enhancement of functional characteristics of blueberry juice fermented by Lactobacillus plantarum. LWT 2021, 139, 110590. [CrossRef] 
23. Kwaw, E.; Ma, Y.; Tchabo, W.; Apaliya, M.T.; Wu, M.; Sackey, A.S.; Xiao, L.; Tahir, H.E. Effect of lactobacillus strains on phenolic profile, color attributes and antioxidant activities of lactic-acid-fermented mulberry juice. Food Chem. 2018, 250, 148-154. [CrossRef] [PubMed]

24. Zhou, Y.; Wang, R.; Zhang, Y.; Yang, Y.; Sun, X.; Zhang, Q.; Yang, N. Biotransformation of phenolics and metabolites and the change in antioxidant activity in kiwifruit induced by Lactobacillus plantarum fermentation. J. Sci. Food Agric. 2020, 100, 3283-3290. [CrossRef]

25. Liao, X.-Y.; Guo, L.-Q.; Ye, Z.-W.; Qiu, L.-Y.; Gu, F.-W.; Lin, J.-F. Use of autochthonous lactic acid bacteria starters to ferment mango juice for promoting its probiotic roles. Prep. Biochem. Biotechnol. 2016, 46, 399-405. [CrossRef] [PubMed]

26. Pisoschi, A.M.; Pop, A.; Cimpeanu, C.; Predoi, G. Antioxidant capacity determination in plants and plant-derived products: A review. Oxidative Med. Cell. Longev. 2016, 2016. [CrossRef]

27. Santos-Sánchez, N.F.; Salas-Coronado, R.; Villanueva-Cañongo, C.; Hernández-Carlos, B. Antioxidant Compounds and Their Antioxidant Mechanism; IntechOpen: London, UK, 2019.

28. Preethi, K.; Vijayalakshmi, N.; Shamna, R.; Sasikumar, J. In vitro antioxidant activity of extracts from fruits of Muntingia calabura Linn from India. Pharmacogn. J. 2010, 2, 11-18. [CrossRef]

29. Muhialdin, B.J.; Kadum, H.; Zarei, M.; Hussin, A.S.M. Effects of metabolite changes during lacto-fermentation on the biological activity and consumer acceptability for dragon fruit juice. LWT 2020, 121, 108992. [CrossRef]

30. Wu, C.; Li, T.; Qi, J.; Jiang, T.; Xu, H.; Lei, H. Effects of lactic acid fermentation-based biotransformation on phenolic profiles, antioxidant capacity and flavor volatiles of apple juice. LWT 2020, 122, 109064. [CrossRef]

31. Hashemi, S.M.B.; Jafarpour, D. Fermentation of bergamot juice with Lactobacillus plantarum strains in pure and mixed fermentations: Chemical composition, antioxidant activity and sensorial properties. LWT 2020, 131, 109803. [CrossRef]

32. Hur, S.J.; Lee, S.Y.; Kim, Y.-C.; Choi, I.; Kim, G.-B. Effect of fermentation on the antioxidant activity in plant-based foods. Food Chem. 2014, 160, 346-356. [CrossRef]

33. Friedman, M.; Jürgens, H.S. Effect of $\mathrm{pH}$ on the stability of plant phenolic compounds. J. Agric. Food Chem. 2000, 48, 2101-2110. [CrossRef]

34. Nurhayati, R.; Frediansyah, A.; Rachmah, D.L. Lactic Acid Bacteria Producing Inhibitor of Alpha Glucosidase Isolated from Ganyong (Canna Edulis) and Kimpul (Xanthosoma sagittifolium). In IOP Conference Series: Earth and Environmental Science; IOP Publishing: Bristol, UK, 2017; p. 012009.

35. Wang, Z.; Hwang, S.H.; Lee, S.Y.; Lim, S.S. Fermentation of purple Jerusalem artichoke extract to improve the $\alpha$-glucosidase inhibitory effect in vitro and ameliorate blood glucose in $\mathrm{db} / \mathrm{db}$ mice. Nutr. Res. Pract. 2016, 10, 282. [CrossRef] [PubMed]

36. Li, X.; Wang, N.; Yin, B.; Fang, D.; Zhao, J.; Zhang, H.; Wang, G.; Chen, W. Lactobacillus plantarum X1 with $\alpha$-glucosidase inhibitory activity ameliorates type 2 diabetes in mice. RSC Adv. 2016, 6, 63536-63547. [CrossRef]

37. Mazlan, F.A.; Annuar, M.S.M.; Sharifuddin, Y. Biotransformation of Momordica charantia fresh juice by Lactobacillus plantarum BET003 and its putative antidiabetic potential. PeerJ 2015, 3, e1376. [CrossRef] [PubMed]

38. Aguilar-Zarate, P.; Cruz, M.A.; Montañez, J.; Rodriguez-Herrera, R.; Wong-Paz, J.E.; Belmares, R.E.; Aguilar, C.N. Gallic acid production under anaerobic submerged fermentation by two bacilli strains. Microb. Cell Factories 2015, 14, 1-7. [CrossRef] [PubMed]

39. Krishnaveni, M.; Dhanalakshmi, R. Qualitative and quantitative study of phytochemicals in Muntingia calabura L. leaf and fruit. World J. Pharm. Res. 2014, 3, 1687-1696.

40. Degrain, A.; Manhivi, V.; Remize, F.; Garcia, C.; Sivakumar, D. Effect of lactic acid fermentation on color, phenolic compounds and antioxidant activity in African nightshade. Microorganisms 2020, 8, 1324. [CrossRef] [PubMed]

41. Zha, J.; Koffas, M.A. Production of anthocyanins in metabolically engineered microorganisms: Current status and perspectives. Synth. Syst. Biotechnol. 2017, 24, 259-266. [CrossRef]

42. Rodríguez, H.; Landete, J.M.; de las Rivas, B.; Muñoz, R.J.F.C. Metabolism of food phenolic acids by Lactobacillus plantarum CECT 748T. Food Chem. 2008, 107, 1393-1398. [CrossRef]

43. Zha, J.; Wu, X.; Gong, G.; Koffas, M.A. Pathway enzyme engineering for flavonoid production in recombinant microbes. Metab. Eng. Commun. 2019, 9, e00104. [CrossRef]

44. Adefegha, S.A.; Oboh, G.; Ejakpovi, I.I.; Oyeleye, S.I. Antioxidant and antidiabetic effects of gallic and protocatechuic acids: A structure-function perspective. Comp. Clin. Pathol. 2015, 24, 1579-1585. [CrossRef]

45. Al-Salih, R.M. Clinical experimental evidence: Synergistic effect of Gallic acid and tannic acid as Antidiabetic and antioxidant agents. Thi-Qar Med. J. 2010, 4, 109-119.

46. Punithavathi, V.R.; Prince, P.S.M.; Kumar, R.; Selvakumari, J. Antihyperglycaemic, antilipid peroxidative and antioxidant effects of gallic acid on streptozotocin induced diabetic Wistar rats. Eur. J. Pharmacol. 2011, 650, 465-471. [CrossRef] [PubMed]

47. Motevaseli, E.; Shirzad, M.; Raoofian, R.; Hasheminasab, S.-M.; Hatami, M.; Dianatpour, M.; Modarressi, M.-H. Differences in vaginal lactobacilli composition of Iranian healthy and bacterial vaginosis infected women: A comparative analysis of their cytotoxic effects with commercial vaginal probiotics. Iran. Red Crescent Med. J. 2013, 15, 199. [CrossRef] [PubMed]

48. Kosem, N.; Han, Y.-H.; Moongkarndi, P. Antioxidant and cytoprotective activities of methanolic extract from Garcinia mangostana hulls. Sci. Asia 2007, 33, 283-292. [CrossRef]

49. Re, R.; Pellegrini, N.; Proteggente, A.; Pannala, A.; Yang, M.; Rice-Evans, C. Antioxidant activity applying an improved ABTS radical cation decolorization assay. Free Radic. Biol. Med. 1999, 26, 1231-1237. [CrossRef] 
50. Cecchini, S.; Fazio, F. Assessment of Total Antioxidant Capacity in Serum of Heathy and Stressed Hens. Animals 2020, 10, 2019. [CrossRef]

51. Benzie, I.F.; Strain, J.J. The ferric reducing ability of plasma (FRAP) as a measure of "antioxidant power": The FRAP assay. Anal. Biochem. 1996, 239, 70-76. [CrossRef]

52. Zulueta, A.; Esteve, M.J.; Frígola, A. ORAC and TEAC assays comparison to measure the antioxidant capacity of food products Food Chem. 2009, 114, 310-316. [CrossRef]

53. Telagari, M.; Hullatti, K. In-Vitro $\alpha$-amylase and $\alpha$-glucosidase inhibitory activity of Adiantum caudatum Linn and Celosia argentea Linn extracts and fractions. Indian J. Pharmacol. 2015, 47, 425.

54. Saul, R.; Molyneux, R.; Elbein, A. Studies on the mechanism of castanospermine inhibition of $\alpha$-and $\beta$-glucosidases. Arch. Biochem. Biophys. 1984, 230, 668-675. [CrossRef]

55. Warren, F.J.; Zhang, B.; Waltzer, G.; Gidley, M.J.; Dhital, S. The interplay of $\alpha$-amylase and amyloglucosidase activities on the digestion of starch in in vitro enzymic systems. Carbohydr. Polym. 2015, 117, 192-200. [CrossRef] [PubMed] 